\title{
Development of Academic Administration Graduate of Faculty of Education Mahachulalongkornrajavityalaya University
}

\author{
Phramaha Yannawat Thitavaddhano1, Phramaha Sombat Dhanapaññ², PhrakhruOpatnontakitti \\ (Sakda Obhāso) ${ }^{3}$, Booncherd Chamnisast ${ }^{4}$ \\ ${ }^{1,2,3,4}$ Faculty of Education, Mahachulalongkornrajavidyalaya University, Thailand \\ 1yannawat.bud@mcu.ac.th, ${ }^{2}$ Sb20300@gmail.com, ${ }^{3}$ sakda_2543@hotmail.com, ${ }^{4}$ booncherd.chum@mcu.ac.th
}

\begin{abstract}
The purpose of this research article was to propose development of academic administration graduate in Faculty of Education Mahachulalongkornrajavidyalaya University. Mixed methods research with three steps was conducted. Step 1 was to study academic administration graduate in Faculty of Education Mahachulalongkornrajavidyalaya University using documentary study and interview 15 administrators and lecturers. Step 2 was to study the process of academic administration graduate using seminar with 12 experts. Step 3 was to develop and evaluate process of academic administration graduate using focus group discussion with 5 experts, and evaluated by conducting try out in Faculty of Education. There were 30 administrators and lecturers as a target group and were selected by purposive sampling. Research results indicated that process of academic administration graduate in Faculty of Education Mahachulalongkornrajavidyalaya University was eight methods of administration (Atthavithi) which consisted of 1) curriculum administration, 2) learning process management, 3) educational media, innovation and technology administration, 3) management of learning sources, 5) learning assessment, 6) educational supervision, 7) research for educational quality development, and 8) quality assurance system. Evaluation results for process of academic administration graduate in Faculty of Education Mahachulalongkornrajavidyalaya University was shown overall at the highest level
\end{abstract}

Index Terms

Development, Academic Administration Graduate, Faculty of Education, Mahachulalongkornrajavityalaya University

Article Received: 10 August 2020, Revised: 25 October 2020, Accepted: 18 November 2020

\section{Introduction}

Changing and competition from the 20th century world to the 21 st century world, or in current world, there are various changes establish policies by creating intelligence and innovation and using knowledge and research mechanisms to develop, must have a strong higher education system. There is a driving force that makes every organization adapt for stable progress and is sustainable with management in accordance with the change and strive for excellence in all areas. The key factors that will be able to face the changing conditions and the challenges that have already arisen and what will happen in the future is the quality of the people because in the present age and in the future the main engine for driving prosperity is not land, labor, raw materials, or investment, but it will be wisdom and knowledge. As the result, current world society is a knowledge-based society [1] including to comply with the policy model Thailand 4.0 according to the economic development plan and the National Society No. 12 (B.E.2560-2564), there are changes in society in various forms having an impact on education especially in Thai society. Education is necessary to develop personnel to keep up with the changes that occur developing quality people in order to become a vital force in the country's development. Universities are the most important educational institutions in the country, providing knowledge and developing learners in various fields in order to be ready to go out and live in the society as well. The production of personnel to the society is not only improving and promoting knowledge and professional competence, but also in cultivating a positive attitude towards the profession. It also changes attitudes, values and beliefs that have a great influence on professional practice. If a person has a positive attitude towards his or her profession, it will make the task of doing something easy and caring for the performance of their duties to the fullest. There was also a sense of pride and joy at work [2].

In higher education, it is an education that elevates thinking, intelligence and expression that is a high-level manpower to the country which is a person who wants to increase their potential, increase their knowledge and raise their standards for higher efficiency. This will lead to academic and professional advancement. The influencing factor is the social, economic, age of education received. Everything is important because of the fact that individuals come to study in order to gain knowledge, abilities, as well as skills that are suitable for the degree that each person comes to study and upon graduation can find a job that meets their knowledge, abilities or skills have studied [3].

Therefore, knowledge generation is considered to be the most important objective of higher education because education at this level is a combination of experienced individuals and has a more academic basis than any other institution in society. The burden of academic management as well as professional development is essential because education at other levels especially at the elementary level and secondary education, too. The academic necessity at both levels mentioned is not profound and concentrated enough to be ready in order to develop academic knowledge [4].

Mahachulalongkornrajavidyalaya University, which is an autonomous university, is a juristic person. There are principles and rules for the development of personnel according to the Mahachulalongkornrajavidyalaya University Act B.E. 2540 (1997) stipulated in Section 6 that 
"the university shall be an educational and research place. The objective is to study, research, promote and provide Buddhist education to monks, novices and laymen including the preservation of arts and culture [5] later, the Graduate School of Mahachulalongkornrajavidyalaya University has been established based on the practice of the order of the Synod Education of the Sangha University in 1969 by the Graduate School of Mahachulalongkornrajavidyalaya University has four missions: producing graduates, research and development in promoting Buddhism and providing academic services to society and in the preservation of art and culture [6].

The Faculty of Education opened in 1961 as the second faculty following the Faculty of Buddhism at present, Department of Educational Psychology and Guidance Department of Educational Administration Department of Curriculum and Instruction Bali Preparatory School Pali Satit Education School. There are many other work groups or special projects with the educational management objectives of the Faculty of Education as follows: 1) to provide education for monks, novices and general public to have knowledge and ability in the science of teachers, management of education, teaching and propagation of Buddhism, 2) to produce graduates who have good practice, inquisitiveness, thinking, and being a leader in mind and wisdom, known to sacrifice for Buddhism and society, 3) to apply and develop innovation and technology for education, research and service, 4) to promote and disseminate knowledge of education and Buddhism to society, and to preserve art and culture maintain identity and Thai wisdom [7].

The role of the university in the status of a higher education institution has to pioneer knowledge. This gives people additional knowledge and points them knowledge to be beneficial in social development. Undergraduate education is for the purpose of utilizing basic knowledge while graduate studies, which are higher education arrangements in higher education institutions to develop, seek and apply knowledge and expertise in a deep area to develop the work can solve problems in various areas [8] with quality graduate education. There are four factors that will be identified, namely, curriculum, teaching and learning system, teachers and students [9].

The quality of the graduates to be good depends on the graduate administration in curriculum management, library, information technology and modern media, and adequate budget highly competent personnel by field coordination and cooperation among similar institutions. Administrators should seek external funding [10] by providing higher education. Knowledge is a key component, or it could be said that academic administration is the first priority of the administration of higher education because academic administration is the main task that is essential to achieving the goals of the school administration and the quality of the learners [11].

It is the reason to develop academic administration at the graduate level of the Faculty of Education because academic administration is the most important part of the management of higher education with such problems and reasons. The researcher is interested in researching Development of Academic Administration Process for Graduate Studies, Faculty of Education, Mahachulalongkornrajavidyalaya
University. This will benefit the academic administration process at the graduate level, Faculty of Education, Mahachulalongkornrajavidyalaya University to serve as a guideline for administrators to apply in academic administration which will benefit the development of people, society and the country in the future.

\section{Research Objectives}

The purpose of this research article was to propose development of academic administration graduate in Faculty of Education Mahachulalongkornrajavidyalaya University.

\section{Research Methods}

This research was mixed methods research with 3 steps of research methods as follows: Step 1: Study academic administration at the graduate level, Faculty of Education, Mahachulalongkornrajavidyalaya University by studying documents related to academic administration at the graduate level, Faculty of Education, Mahachulalongkornrajavidyalaya University and interviewed 15 of administrators and teachers and data was analyzed by using content analysis.

Step 2 Study the process of academic administration at the graduate level, Faculty of Education, Mahachulalongkorn rajavidyalaya University by studying documents related to the principles and methods of postgraduate academic administration and organized seminars for stakeholders and 12 experts and analyzed the data with content analysis.

Step 3 Develop and evaluate the academic administration process at the graduate level, Faculty of Education, Mahachulalongkornrajavidyalaya University by developing the process of academic administration at the graduate level with focus group discussion group of 5 experts and evaluating the graduate academic administration process with an experiment in the Faculty of Education. There were 30 administrators and teachers in the research target group. The statistics for data analysis were percentage, mean and standard deviation.

\section{Results}

Academic administration process at the graduate level, Faculty of Education, Mahachulalongkornrajavidyalaya University is Atthavithi, it is an academic administration process of 8 methods as follows:

1. Curriculum administration consisted of 1) Study, analyze academic curriculum documents, disciplines, problems and needs of society, and community and local, 2) analyze the strategic environment of the university following to the health assessment to determine the desired vision, mission, goals and characteristics by the participation of all parties, including the relevant committees, 3) create a curriculum structure, and given in the course of study in line with the vision goals as appropriate, 4) appropriate curriculum implementation in teaching and learning management and curriculum administration, 5) curriculum supervision and curriculum evaluation, 6) follow up and evaluate the curriculum implementation every 5 years or as appropriate of the curriculum, 7) improve and develop the curriculum as appropriate. 
2. Learning management process consisted of 1) mixing knowledge to balance cultivate virtue, 2) arrangement of teaching supervision for staff professors in the field with emphasis on supervisory cooperation and assistance in the form of peer support, to develop joint teaching or other forms according to ability, 3) setting the atmosphere and environment and learning things to facilitate the organization of the learning process, 4) bringing local wisdom or network of parents of local communities to participate in Teaching and learning as appropriate, 5) promote the development of teachers on a regular basis to develop the learning process as appropriate, 6) encouraging teachers to organize learning processes by organizing content and activities in accordance with the interests. The aptitude of the learners is to practice the skills of thinking process, situation management application of knowledge to prevent and solve problems. Learning from real and practical experience continuous promotion of the love of reading and keen on knowledge, and 7) encouraging teachers to create plans to promote learning management with focus on students.

3. Media Management, Innovation and Educational Technology consisted of 1) evaluation of the development of media use innovation and technology for education, 2) provide media and technology for use in teaching and learning management and academic development, 3) coordinate production and development of media, innovation and technology for teaching and learning, 4) study and analyze the need for media and technology for teaching and learning management and academic administration, 5) promote production, development of modern teaching and learning materials and innovations.

4. Management of learning resources consisted of 1) preparing documents to disseminate learning resources for university personnel, organizations, departments and other universities, 2) Development of new learning resources and coordination with other universities, organizations, agencies and the institution that provides the study, 3) encouraging teachers to use learning resources within the university and outside the university in organizing the learning process, and 4) survey of learning resources related to the development of educational quality in both the university and the local community.

5. Evaluation consisted of 1) establish procedures for evaluating results, evaluating results for study requests in accordance with educational standards learning, learning unit, learning management plan, and organizing learning activities, 3) encouraging teachers to measure results and assess learning and teaching results with emphasis on real assessment of the processes, practices and results.

6. Educational Supervision consisted of 1) organization of academic supervision and teaching system within the Faculty of Education Mahachulalongkornrajavidyalaya University, 2) conducting academic supervision and teaching in a diverse and appropriate format for the Faculty of Education Mahachulalongkornrajavidyalaya University, 3) Monitoring and coordination to develop educational supervision of the Faculty of Education Mahachulalongkornrajavidyalaya University, 4) an exchange of knowledge and experience in managing educational supervision within Mahachulalongkornrajavidyalaya University including the education supervision network in other universities, and 5) evaluating the results of educational supervision in the faculty of education Mahachulalongkornrajavidyalaya University.

7. Research for Educational Quality Development consisted of 1) research analysis, principles of management and academic quality development in the overall of the Faculty of Education, Mahachulalongkornrajavidyalaya University, 2) coordinate study, analysis and research as well as dissemination of research results including the development of the quality of teaching and academic work with universities, organizations, agencies and other institutions, and 3) encourage staff teachers to study, analyze, research to improve learning quality for each field of study.

8. Quality Assurance System consisted of 1) setting criteria for assessing the achievement goals of the Faculty of Education Mahachulalongkornrajavidyalaya University according to educational standards and indicators of the Ministry of Higher Education, Science, Research and Innovation Criteria and assessment methods of the Office for Educational Standards and Quality Assessment, 2) organization of the Faculty of Education structure to support the organization of the quality assurance system within Mahachulalongkornrajavidyalaya University, 3) implementation of work development according to the plan and follow up internal audit and assessment to continuously improve and develop, 4) coordinating with universities and other agencies to improve and develop an internal quality assurance system and the development of educational quality according to the educational quality assurance system, 5) coordination with the Office of the Higher Education Commission Ministry of Science for the assessment of educational quality according to the quality assurance system, and 6) planning of educational quality development under the educational quality assurance system to achieve the achievement goals of the Faculty of Education, Mahachulalongkornrajavidyalaya University.

\section{Discussions}

The researcher found important points to be discussed. The process of academic administration at the graduate level of the Faculty of Education Mahachulalongkornrajavidyalaya University is Atthavithi, it is an academic administration process in 8 ways: 1) Curriculum Management, 2) learning management process, 3) innovation media management and educational technology, 4) learning resources management, 5) evaluation measurement, 6) educational supervision, 7) research for educational quality development, and 8) quality assurance system. These eight methods of academic administration are very important principles in academic administration and cover education management at the tertiary level.

As Uthai Boonprasert said that academic work is the main task and the biggest task of the system. It is the work at the heart of the school, [12] related with Pichai Sangiemjit's idea that academic administration is of great importance and is considered to be the main task in the educational administration of the school. This is because education is the foundation for human development. To be able to seek knowledge keep pace with the world [13], related with Fry, Ketteridge, and Marshall, academic administration is the 
implementation of all activities in the school that are involved in the development and improvement of the teaching and learning of students. It works well, is most effective [14] as the Chankanart Cheunchei suggested that continuing education in higher education institutions is an important component. It consists of philosophy and principles target group, aim, structure, management system, teaching course methods of conducting studies educational materials and learning resources monitoring and evaluation grading and transfer of grades [15]. It was also found that it was consistent with the research of Nanthawan informed that the research results showed that Model of Effective Cooperative Academic Administration of Private Vocational Colleges in Northeastern Region consists of curriculum development work measurement and evaluation work instructional media and academic services and libraries consultation teamwork or team building quality control [16].

According to Pornthep Saranan's research that the research results showed Development of Academic Management Model Rajamangala University of Technology Suvarnabhumi. It consists of supervision and personnel development, academic promotion and control teaching and learning academic service courses. The measurements and evaluations [17] were consistent with research by Phrakrupalad Thanakrishna Kittipañño (Ritnaka), Suddhipong Srivichai, Peeravat Chaisuk. Academic administration in the temple charity school in Buddhism consists of course Administration Measurement and Evaluation Management, Instructional media management, Educational Supervision and conducting teaching [18] and related with the research of Rattana Sanitnoi, Narong Pimsan, Sirikarn Tanawutpornpinit where the research results showed that the academic administration of the three-language schools at the primary level consists of providing an atmosphere that facilitates learning, internal quality, assurance curriculum development, internal supervision, measure organizing, learning experiences, and the production and use of media technology [19].

As for the evaluation of the academic administration process at the graduate level, Faculty of Education, Mahachulalongkornrajavidyalaya University. Overall, it is at the highest level. It is because this research has a mixed research process both quantitative research and qualitative research and there are 3 research steps: Step 1: studying academic administration at the graduate level, Faculty of Education, Mahachulalongkornrajavidyalaya University by studying documents and interviewing 15 executives and professors. Step 2: studying the process of academic administration at the graduate level by organizing seminars, 12 stakeholders and experts, and the third step, developing and evaluating the graduate academic administration process. It was developed with a discussion group of 5 experts and evaluated by using experiments in the Faculty of Education. There were 30 administrators and professors in this research population. It is related to with Saman Asavapoom said that the inspection by a qualified. The researcher will present the developed model to 15-20 experts with a feasibility and feasibility assessment form, as well as additional recommendations and verified by experiment in which the researcher conducted a trial using the model that was developed in real conditions or simulated events. According to the design schemes to observe, collect information and opinions to relevant persons to be used in the further improvement of the model after obtaining the data from the quality inspection and the said format. The researcher should make further improvements along with a summary of information, comments and suggestions that are important to the model and its further application [20].

\section{Recommendations}

\section{A. Recommendations for Practices}

1) Government and the Ministry of Higher Education, Science, Research and Innovation. The policy should be established to promote and support academic administration at the graduate level of the Faculty of Education, Mahachulalongkornrajavidyalaya University.

2) Mahachulalongkornrajavidyalaya University Budget should be supported for academic administration at the graduate level, Faculty of Education, Mahachulalongkornrajavidyalaya University for more efficient teaching and learning management.

3) Faculty of Education, Mahachulalongkorn- rajavidyalaya University should apply the body of knowledge from this research as a policy on academic administration at the graduate level.

\section{B. Recommendations for Further Research}

1) From results of this research, Mahachulalongkorn rajavidyalaya University should be defined as a vision and strategy for academic administration at the graduate level in the Faculty of Education and other faculties.

2) From results of this research, Faculty should be developed into a complete manual for use in academic administration at the graduate level in the Central Education Faculty, Campus and Sangha College.

\section{Conclusion}

From this research articles, the purpose of this research was to propose the development of the process of postgraduate academic administration, Faculty of Education, Mahachulalongkornrajavidyalaya University. It is a research that combines both quantitative research and qualitative research. There are 3 research steps which are: Step 1: studying academic administration at graduate level with a study of documents and interviews. Step 2: studying the process of academic administration at graduate level by organizing seminars for stakeholders and experts, and Step 3: developing and evaluating the graduate academic administration process by developing a discussion group with experts and evaluated by using experiments in the Faculty of Education. The research result is an academic administration process at the graduate level of Faculty of Education, Mahachulalongkornrajavidyalaya University, which is Atthavithi. It is an academic administration process of 8 methods, consisting of 1) course administration, the existing curriculum administration has been developed to be appropriate for the current situation. It consists of a purpose which will identify the conduct of the student and content in teaching and learning management including the criteria for 
the selection of subjects and the criteria for teaching and teaching appropriate, 2) the learning management process, developing the learning process with a learner-centered focus. There is an opportunity to seek knowledge to learners and the teachers change the chapter from the donor to the partner of knowledge and provide learning experiences for learners appropriately and should have a variety of learning arrangements. 3) Management of innovative media and educational technology consisted of management of media, materials, equipment and methods for transferring knowledge, skills, experience from knowledge sources to learners in order to learn faster and more efficiently by saving study time and provide learning motivation for learning using several educational innovations both devices and online media. 4) Management of learning resources development of learning resources to create new knowledge that resulted in the learner being a person of learning, able to acquire knowledge for themselves from various learning sources in modern times. 5) Evaluation measurement, it is the evaluation measurement with the learning outcomes assessed, it has to be conducted in accordance with the content being taught, learners' development, behavior, observation, behavior, learning activities and testing along with the teaching and learning process. Tests must be measured both measuring and evaluating, both knowledge, ideas, abilities, skills, attitudes, morals and ethics. There are a wide variety of measuring instruments. The results are measured and evaluated continuously. 6) Educational supervision, the teacher in the supervisory role advises learners on how to improve the teaching and use of teaching materials with emphasis on supervisory process skills consists of an assessment of working conditions Ordering the tasks to do Coordination design, and 7) research to improve educational quality research to improve educational quality by allowing teachers to integrate research processes or integrate them into teaching and learning management to develop learner quality. Learning research process is a part of the learning management process. This starts with analyzing problems, planning, solving problems, implementing solutions, collect information, summarize the problem solving, report and apply the research results, and 8) the quality assurance system. Quality assurance system development by doing a systematic activity or mission according to the plan with quality control quality inspection, and quality assessment until causing confidence in the quality and the standard of indicators, systems and processes of production, productivity, and results of management studies effectively and efficiently as in Fig.1.
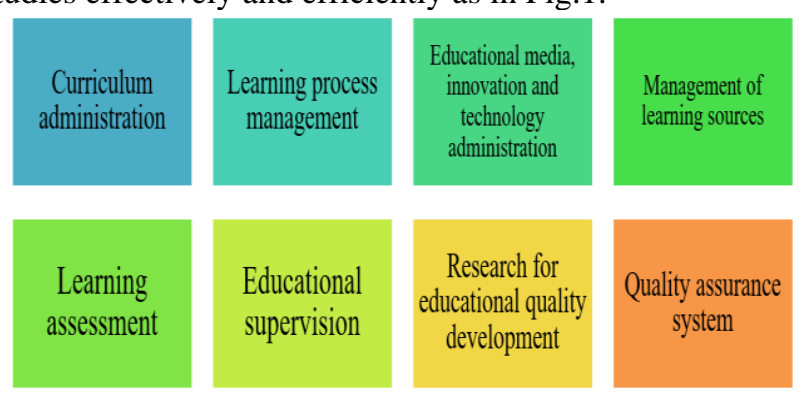

Fig. 1 Development of Academic Administration Graduate of Faculty of Education Mahachulalongkornrajavityalaya University

\section{References}

[1] W. Panich, Knowledge management, Practitioner's edition, Bangkok: Mental Health, 2008.

[2] The National Economic and Social Development Board, National Economic and Social Development Plan No. 9 B.E. Guybooks, 2002.

[3] Adul Wiriyavejkul, Lifelong Learning, Bangkok: Print Pro, 1999.

[4] P. Sinarat, Thailand qualifications framework, Thailand qualifications framework, 2nd edition, Bangkok: Chulalongkorn University Press, 2012

[5] Human Resource Management Group, Central Division, Office of the President. Documents supporting the entrance examination for university personnel Mahachulalongkornrajavidyalaya, Bangkok: Mahachulalongkornrajavidyalaya, 2017.

[6] Mahachulalongkornrajavidyalaya University, Self-Assessment Report, Bangkok: Mahachulalongkorn rajavidyalaya University, 2017.

[7] Department of Educational Administration, Faculty of Education, Mahachulalongkornrajavidyalaya University, Graduate Study Manual, 5th edition, Mahachulalongkornrajavidyalaya Publishing House, 2015.

[8] Thailand qualifications framework, 2nd edition, Bangkok: Chulalongkorn University Press, 2012

[9] Khuptkanjanakul, "A causal component analysis of the teaching of the teacher in Teachers College ", Ph.D. Thesis, Chulalongkornrajavidyalaya, 1989.

[10] A. Wiriyavejkul, Graduate Quality Indicator for Higher Education Institutions, Bangkok: Mahidol University, 1998. 
[11] J. Wannasri. Educational institutions, Phitsanulok: Rattanasuwan Printing, 2014, page 1.

[12] Uthai Boonprasert. Brainstorming meeting, Bangkok: Chulalongkorn University Press, 1997.

[13] P. Saengiamjit. Academic scope: Teaching documents, academic administration, Ubon Ratchathani: Ubon Ratchathani Rajabhat Institute, 1998.

[14] Fry, Ketteridge, and Marshall, A Handbook for Teaching and Learning in Higher Education: Enhancing Academic Practice, 3rd ed., New York: Taylor \& Francis, 2009.

[15] C. Nartchuensei, Model of continuing education in private higher education institutions Doctor of Education Thesis, Srinakharinwirot University, 2004.

[16] N. Jangsuk, Development of an effective participatory academic administration model of a major vocational college, Northeast Thesis in Doctoral Philosophy. Sakon Rajabhat University, 2014: 171272.

[17] P. Sanan, Development of Academic Management Model, Rajamangala University of Technology Suvarnabhumi. Dissertation, Industrial Education, Doctor of Education. King Mongkut's Institute of Technology Ladkrabang, 2013:188-193.

[18] Phrakrupalad Thanakrishna Kittipañño (Ritnaka), Suddhipong Srivichai, Peeravat Chaisuk, "Process of academic administration development for Buddhist temple charity schools", Journal of Educational Review Faculty of Educational in MCU. 7(2), 2020: 39-52.

[19] R. Sanitnoi, Narongpimsan, S.Tanawutpornpinit. "Academic administration model for trilingual kindergarten school", Journal of Educational Review Faculty of Educational in MCU, 7(2), 2020: 203-219.

[20] S. Asavapoom, Use of research and development in a Doctoral thesis, Ubon Ratchathani Rajabhat University Journal, (July-December 2007): 83-84 